\title{
Coping with Library Anxiety Using Interactive Technology
}

\author{
Ida F Priyanto \\ Universitas Gadjah Mada
}

\begin{abstract}
A library has been viewed as a place for learning outside of the classroom. The information technology that has resulted in digital library does not replace a library as a place. It enhances the library's role as a learning place. However, students often experience what is called as "library anxiety" when visiting a library, especially when they visit it for the first time. Adding more technological applications will make current users get better information. And it will also help cope with any library anxiety.
\end{abstract}

Keywords: coping, library anxiety, interactive technology

\section{Introduction}

Technology has brought changes to the ways libraries serve users. It also affects the way librarians provide instruction to users. The libraries began their big change with the use of computerized catalogs in the 1980s-1990s. This change affected the way libraries provided services. Library automation has changed the way a library serves the users. In addition, the presence of Internet in the libraries also affects the way libraries provide services. Currently information technology has become an important part of a library.

Libraries have continuously developed their online services and resulted in the existence of digital libraries. However, digital libraries do not make the library space unimportant. Lippincott (2005) said that physical spaces are still important in higher education including libraries. She 
further stated that libraries could be viewed as learning spaces outside of the classrooms where students could study both individually and together with other students. The emergence of bookless libraries nowadays also emphasizes the importance of library space in the real world besides virtual one.

\section{Library Anxiety: Past and Present}

Matthews (2013) identified that library users have three potential reasons for using a library or information service, they go to the library to do their assignments or projects, for personal reasons, to fulfill their information needs or for doing any activities. Therefore, it is understandable that academic libraries need to learn the characteristics of the users and what and how to fulfill their needs. This is emphasized by Fidishun (2007) who viewed the importance of librarians to understand why and how users come to the library; while Bolan, Canada, and Cullin, (2007) suggested that "librarians have to listen more, trust more, and be willing to relinquish some control to allow customers of all ages and backgrounds to have the best library experience possible" (p.41). In this way, librarians may learn the views of their libraries from the perspective of their users and the users' ideas of a good library.

There are students who do not know anything about library services and when they have to go to the library, they will feel so worried. This behavior was studied by Constance Mellon (1986) who found out that four causes of the students' uncomfortable feelings, i.e. "(1) library size, (2) lack of knowledge about location of things in the library, (3) how to begin a library works, and (4) what to do in the library" (p. 162). Mellon's study shows that the first two causes are from the physical space of the library; while the other two causes are from research process. In other words, being in a library without knowing the location of things will result in lack of confidence; so are lack of understanding of what to do and how to begin in the library. The uncomfortable feeling appears when students have to visit the library or when they have assignments relating to library services. Jiao and Onwuegbuzie (2004) mentioned that library physical comfort related 
to students' comfort with the library and satisfaction of space access. New students have to familiarize themselves with the library environment. They should learn how they can benefit from the library services. Robertson and Jones (2007) stated that "walking into a physical library for the first time and attempting to locate a particular area within the facility can potentially be a frustrating experience" (p.60). Swigon (2011) emphasized that library anxiety "certainly exists and should be recognized as a potential barrier to access to information in libraries" (p. 149). Lee (2012) stated that students "were not aware of what the academic library had to offer them and were provided limited or no opportunities to learn" (p. 84).

There is another consideration about users. Krotoski (2010) mentioned the importance of understanding current library users. He stated that "library visitors of the future will be demanding. They will expect interactive catalogues to contain every permutation of possible data, and for it to be accessible on multiple devices at any time" (p. 633). Shafique, Shafiqur-Rehman, \& Mahmood (2012) also stated that "information needs and expectations are continuously changing in the rapidly changing information scenario. Libraries need to re-orient their collections, services, and facilities to keep pace with these advancements" (p. 3). Technology has been with the new generation of students and they can adapt with it easily. By implementing technology to guide and help them when they visit the library, they will have less anxiety when visiting the library.

\section{Library and Current Users}

Current academic library users sometimes still experience library anxiety due to the library size and lack of knowledge about the library facilities, besides not knowing what to do and how to begin in the library. Therefore, the best way of helping and attracting current students who are digital natives is by applying technology in the library in new and innovative ways. Technology will enhance library instruction and information. Technology can be a good medium to share information with students nowadays because they are familiar with technology and therefore the library information will 
be more engaging and entertaining for them. Beard and Bawden (2012) stated that the library of the future must be a place of study that is equipped with excellent computing facilities, common spaces for collaborative work and adequate silent space; while Niegaard (2011) said that the library should be an "intelligent space" (p. 180). Lippincott (2005) emphasized that "the library offers a venue where academic work can be carried out in a social context. As libraries renovate facilities to incorporate technology, they are also making them more suitable for student group work, informal socializing, and ubiquitous computing" (p. 56). Some libraries in Asia have even developed entertainment facilities that are enjoyed by users and the libraries are equipped with gaming areas, gym rooms, and XD theaters. Some people also use a library as a place for their pre-wedding photo taking.

Today's libraries will be appropriate if they implement technology for various services and information for users. Niegaard (2011) mentioned three conditions to consider in relation to the implementation of technology for library facilities and information: (1) users who have new media habits and changes in behavior; (2) changes in the library's resources and tasks; and (3) the growth in self-service facilities. Library space for users is more important than that for collections nowadays. Haas and Stillwell (2010) stated that one of the major concerns in the library is "Space, students want more room to work on their projects" (p. 163). Rasul and Sahu (2011) considered the use of IT has become imperative for the efficient management of modern libraries. In other words, collaboration among librarians, IT people, and architects will help formulate the needs of today's users. Niegard (2011) stated the importance of librarians to work with architects "to accommodate new digital technologies ( $p, 175)$. In this case, the library functions and design and the IT placement are better accommodated and managed.

\section{Application of Interactive Technology to Enhance Library Information}

Based on the need to help and fulfill the needs of library users, the library can enhance its services by developing interactive and real-time information about the library where users can check the number of discussion 
rooms available and can then book the room from the website or their smartphones. This will help students plan their visit to the library. As library seats and computer terminals are limited, real-time information about the number and location of available seats and computer terminals is important. Students can check how many and which seats and computer terminals are available from the interactive screen in the library lobby or via smartphones and tablets. This is useful when the library has many floors. Users can check the available seats and computer terminals before going up and downstairs of the library to look for the free seats and computers.

An interactive and directive catalog will save time too. The library catalog is added with an application that provides shelf information where users can get the collection. Users can check the catalog about the availability of books and other printed materials and the interactive computer screen will show the collection's location. When this is connected with smart shelves, not only the map that a user may get, but the shelf will also notify the user by sound or light. This sort of technology is appropriate for libraries in a developing countries. Some libraries in China have already implemented this technology.

It is hoped that the application of such simple technology will help library users in coping with their confusion when visiting the library and save their time by knowing the location of the room or seat to sit; to find library collection, and possibly to cope with disaster.

\section{Conclusion}

Library as a place still plays an important role. Library users make use of the library to study, to have discussion with others, and to enjoy other library services and activities. The application of such simple technology will definitely help users to save time and cope with their anxiety when they visit the library, especially when they visit the library for the first time. Indeed libraries should bear in mind that the focus of the library is not on the library collection anymore, but "on the user's stay in the library and on the user having access to both physical and digital resources" (Niegaard, 2011, p. 174). 


\section{References}

Beard, C. \& Bawden, D. (2012). University libraries and the postgraduate student: physical and virtual spaces. New Library World, 113(9/10), 439-447.

Bolan, K. Canada, M, and Cullin, R. (2007). Web, library, and teen Services 2.0. Young Adult Library Services. 40-43.

Fidishun, D. (2007). Women and the Public Library: Using Technology, Using the Library. Library Trends, 56(2), 328-343.

Haas, L. \& Stillwell, A. (2010). The library-information technology partnership: Challenges and solutions. Journal of Library Administration, 50, 51-66.

Jiao, Q. and Onwuegbuzie, A. (2004). The impact of information technology on Library Anxiety: The role of computer attitudes. Information Technology and Libraries, 23(4), 138-144.

Krotoski, A. (2010). Libraries of the future. Nature, 468, 633.

Lee, S. (2012). An Exploratory study of library anxiety in developmental education students. Community \& Junior College Libraries, 18, 67-87.

Lippincott, J. (2005). Net generation students and libraries. Educause. Retrieved from http://www.educause.edu/educatingthenetgen/.

Matthews, R. (2013). Valuing Information, Information Services, and the Library: Possibilities and realities. Portal: Libraries and the Academy, 13(1), 91-112.

Mellon, C. (1986). Library anxiety: A grounded theory and its development. College and Research Libraries, 47(2), 160-165.

Niegaard, H. (2011). Library Space and Digital Challenges. Library Trends, 60(1), 174-189.

Rasul, G. \& Sahu,A. (2011). Use of IT and Its Impact onService Quality in an AcademicLibrary. Library Philosophy and Practice. Retrieved from http:// unllib.unl.edu/LPP/

Roberson, J. \& Jones, J.G. (2009). Exploring academic library users' preferences of delivery methods for library instruction: Webpage, digital Game, and other modalities. Reference \& User Services Quarterly, 48(3), 259-269.

Shafique, F., Shafiq-ur-Rehman, \& Mahmood, K. (2012). A Macro Sketch of Users' Needs, Satisfaction, and Library Performance: A Survey of University Libraries in Pakistan. Library Philosophy and Practice. Retrieved from http://digitalcommons.unl.edu/libphilprac/

Swigon, M. (2011). Library anxiety among Polish students: Development and validation of the Polish library anxiety scale. Library \& Information Science Research, 33, 144-150 